\title{
Lactose Hydrolysis in Milk and Dairy Whey Using Microbial $\beta$-Galactosidases
}

\author{
Michele Dutra Rosolen, ${ }^{1}$ Adriano Gennari, ${ }^{1}$ \\ Giandra Volpato, ${ }^{2}$ and Claucia Fernanda Volken de Souza ${ }^{1}$ \\ ${ }^{1}$ Laboratório de Biotecnologia de Alimentos, Programa de Pós-Graduação em Biotecnologia, Centro Universitário UNIVATES, \\ Avenue Avelino Tallini 171, P.O. Box 155, 95900-000 Lajeado, RS, Brazil \\ ${ }^{2}$ Curso de Biotecnologia, Instituto Federal de Educação, Ciência e Tecnologia do Rio Grande do Sul (IFRS), \\ Câmpus Porto Alegre, Porto Alegre, RS, Brazil
}

Correspondence should be addressed to Claucia Fernanda Volken de Souza; claucia@univates.br

Received 29 July 2015; Revised 28 September 2015; Accepted 29 September 2015

Academic Editor: Toshihisa Ohshima

Copyright (C) 2015 Michele Dutra Rosolen et al. This is an open access article distributed under the Creative Commons Attribution License, which permits unrestricted use, distribution, and reproduction in any medium, provided the original work is properly cited.

\begin{abstract}
This work aimed at evaluating the influence of enzyme concentration, temperature, and reaction time in the lactose hydrolysis process in milk, cheese whey, and whey permeate, using two commercial $\beta$-galactosidases of microbial origins. We used Aspergillus oryzae (at temperatures of 10 and $55^{\circ} \mathrm{C}$ ) and Kluyveromyces lactis (at temperatures of 10 and $37^{\circ} \mathrm{C}$ ) $\beta$-galactosidases, both in 3,6 , and $9 \mathrm{U} / \mathrm{mL}$ concentrations. In the temperature of $10^{\circ} \mathrm{C}$, the $K$. lactis $\beta$-galactosidase enzyme is more efficient in the milk, cheese whey, and whey permeate lactose hydrolysis when compared to A. oryzae. However, in the enzyme reaction time and concentration conditions evaluated, $100 \%$ lactose hydrolysis was not reached using the $K$. lactis $\beta$-galactosidase. The total lactose hydrolysis in whey and permeate was obtained with the A. oryzae enzyme, when using its optimum temperature $\left(55^{\circ} \mathrm{C}\right)$, at the end of a $12 \mathrm{~h}$ reaction, regardless of the enzyme concentration used. For the lactose present in milk, this result occurred in the concentrations of 6 and $9 \mathrm{U} / \mathrm{mL}$, with the same time and temperature conditions. The studied parameters in the lactose enzymatic hydrolysis are critical for enabling the application of $\beta$-galactosidases in the food industry.
\end{abstract}

\section{Introduction}

Milk is recognized by its nutritional value as it presents in its composition an elevated concentration of calcium and proteins of biological value. It also has bioactive peptides with a protective function in human health, such as antibacterial, antiviral, antifungal, antioxidant, antihypertensive, and antithrombotic action $[1,2]$.

Dairy whey, such as cheese whey and whey permeate, is widely used in the elaboration of new products due to its lactose, proteins, vitamins, and dietary minerals compositions [3-5]. In addition to their nutritional properties, cheese whey proteins present the capacities of solubility, formation of foam, water absorption, gelatinization, and emulsification. These technological properties of the cheese whey proteins confer beneficial characteristics to foods [6].
However, the lactose present in milk, in dairy products and in whey from dairy industries, limits the consumption of these products by individuals who are lactose intolerant. Intolerance to this sugar is a result of the reduction in the $\beta$-galactosidase enzyme levels in intestinal walls. This enzyme is present in mammals during the breast-feeding period; however, for most of them, the $\beta$-galactosidase activity decreases after the said period, which characterizes primary hypolactasia and brings about symptoms of lactose intolerance. This disorder affects about $70 \%$ of the world adult population [7-10]. According to Mattar and de Campos Mazo [7], in Brazil, the disease occurs in $57 \%$ of the white population and $80 \%$ of black individuals, reaching $100 \%$ of the population of Japanese descent.

The food industry has been seeking to develop lowlactose or lactose-free products. Thus, sugar enzymatic 
hydrolysis from the $\beta$-galactosidase enzyme, generating glucose and galactose monosaccharides, emerges as a key biotechnological process with application in the dairy industry. $\beta$-Galactosidase was first used in the preliminary treatment of milk used in the production of candies and fermented dairy products. This application leads to an enhancement of the sensorial and technological properties of the end products, such as higher sweetness, higher solubility, and decrease in fermentation period $[11,12]$.

Another application for the hydrolysis process aims at adding value to whey, whose improper disposal poses a serious environmental problem. The number of microorganisms capable of metabolizing lactose as a source of carbon is smaller than the number of microorganisms capable of metabolizing glucose and galactose [13]. Therefore, whey lactose enzymatic hydrolysis makes the bioremediation processes and biomolecules and biomass productions viable with the use of these kinds of whey as cultivation media $[14,15]$.

$\beta$-Galactosidases have animal, vegetable, or microbial (bacterium, fungus, and yeast) origins, but the microbial enzymes show a higher productivity, resulting in cost reduction. The $\beta$-galactosidases used in industrial scale must come from Generally Recognized as Safe (GRAS) microorganisms. Enzymes obtained from fungi (Aspergillus oryzae and Aspergillus niger) and yeasts (Kluyveromyces lactis and Kluyveromyces fragilis) show great commercial potential. The choice of the $\beta$-galactosidase source usually depends on the hydrolysis reaction conditions. The ones from fungi present an optimum $\mathrm{pH}$ between 2.5 and 5.4, being usually used for acid whey hydrolysis. The ones obtained from yeasts present optimum pH between 6.0 and 7.0, and its use is more adequate for milk and sweet whey lactose hydrolysis. Other important features for the use of the enzyme in industrial processes include thermostability and the elevated enzymatic activity at low temperature, which enables its application in conditions that do not alter the sensorial and nutritional features of milk and its derivatives $[11,16]$.

In this context, the work aimed at evaluating the influence of enzyme concentration, temperature, and reaction time in the lactose hydrolysis process in milk, cheese whey, and whey permeate, using two commercial $\beta$-galactosidases of microbial origins.

\section{Material and Methods}

2.1. Material. The low fat powdered milk and the powdered cheese whey used for this paper were ceded by Brasil Foods S.A. (Teutônia, Rio Grande do Sul, Brazil). The cheese whey powder was provided by Arla Foods (Porteña, Córdoba, Argentina). The commercial $\beta$-galactosidases enzymes used, Lactomax F30 and Lactomax Pure, obtained from the Aspergillus oryzae (A. oryzae) and Kluyveromyces lactis (K. lactis) strains, respectively, were provided by Prozyn (Butantã, São Paulo, Brazil).

2.2. $\beta$-Galactosidase Assay. The $\beta$-galactosidase activities of the commercial enzymes were assayed using o-nitrophenyl$\beta$-D-galactopyranoside (ONPG) as substrate. The initial rate of formation of free o-nitrophenol (ONP) was recorded spectrophotometrically at $415 \mathrm{~nm}$. One unit of enzyme activity $(\mathrm{U})$ is defined as the amount of enzyme that liberates $1.0 \mu$ mole of o-nitrophenol per minute under assay conditions.

2.3. Milk and Dairy Whey Enzymatic Hydrolysis Process. We added $100 \mathrm{~mL}$ of low fat milk, cheese whey, or whey permeate reconstructed at $5 \%(\mathrm{~m} / \mathrm{v})$ of lactose to $250 \mathrm{~mL}$ Erlenmeyer flasks. The processes of enzymatic lactose hydrolysis were performed using 3,6, and $9 \mathrm{U} / \mathrm{mL}$ concentrations for the $A$. oryzae or $K$. lactis $\beta$-galactosidase in orbital rotation shaker (MA 830, Marconi, Piracicaba, SP, Brazil), at $150 \mathrm{rpm}$, with temperatures of 10 and $55^{\circ} \mathrm{C}$ for the $A$. oryzae enzyme and 10 and $37^{\circ} \mathrm{C}$ for the $K$. lactis $\beta$-galactosidase. These enzymatic concentrations corresponded to $0.1,0.2$, and $0.3 \mathrm{~g} / \mathrm{L}$ of $A$. oryzae $\beta$-galactosidase and to $0.37,0.74$, and $1.11 \mathrm{~g} / \mathrm{L}$ of $K$. lactis $\beta$-galactosidase. After $0,1,2,4,8$, and $12 \mathrm{~h}$ of hydrolysis reaction, we collected samples that were submitted to a $100^{\circ} \mathrm{C}$ for $10 \mathrm{~min}$, so as to inactivate the enzyme, and afterwards we determined the glucose concentration. All the experiments were performed in triplicate.

We calculated the milk and dairy whey lactose hydrolysis efficiency $\left(E_{h}\right)$ according to the following:

$$
E_{h}(\%)=\frac{C_{\mathrm{glu}} \times \mathrm{MM}_{\mathrm{lac}}}{C i_{\mathrm{lac}} \times \mathrm{MM}_{\mathrm{glu}}} \times 100,
$$

where $C_{\text {glu }}$ is glucose concentration, $\mathrm{MM}_{\mathrm{lac}}$ is molar mass of lactose, $C i_{\text {lac }}$ is initial lactose concentration $(50 \mathrm{~g} / \mathrm{L})$, and $\mathrm{MM}_{\mathrm{glu}}$ is molar mass of glucose.

2.4. Determination of Glucose Concentration. The glucose concentration was measured with the oxidase-peroxidase colorimetric method, using the enzymatic kit for glucose determination (Labtest, MG, Brasil) and absorbance reading in spectrophotometer (Genesys 10S UV-Vis, Thermo Scientific, USA) at $505 \mathrm{~nm}$. The glucose concentration was established based on a calibration curve. The analyses were performed in triplicate.

2.5. Statistical Analysis. The glucose concentration results represent the average from three independent experiments, performed in triplicate. The statistical evaluation of the conversion rate of lactose in glucose, present in milk, cheese whey, and permeate, in the different conditions of enzymatic hydrolysis, was performed through the Analysis of Variance (ANOVA), and the significance of the model was verified by the $F$ test. In the significant models, the averages were compared to the Tukey test, in a significance level of $95 \%$ $(p<0.05)$ using the BioEstat 5.0 software.

\section{Results and Discussion}

Figures 1, 2, and 3 show results from the lactose hydrolysis of milk, cheese whey, and permeate, respectively, using the $A$. oryzae (at 10 and $55^{\circ} \mathrm{C}$ ) and $\mathrm{K}$. lactis enzymes (at 10 and $37^{\circ} \mathrm{C}$ ), with a $12 \mathrm{~h}$ reaction. The enzymatic concentrations used 


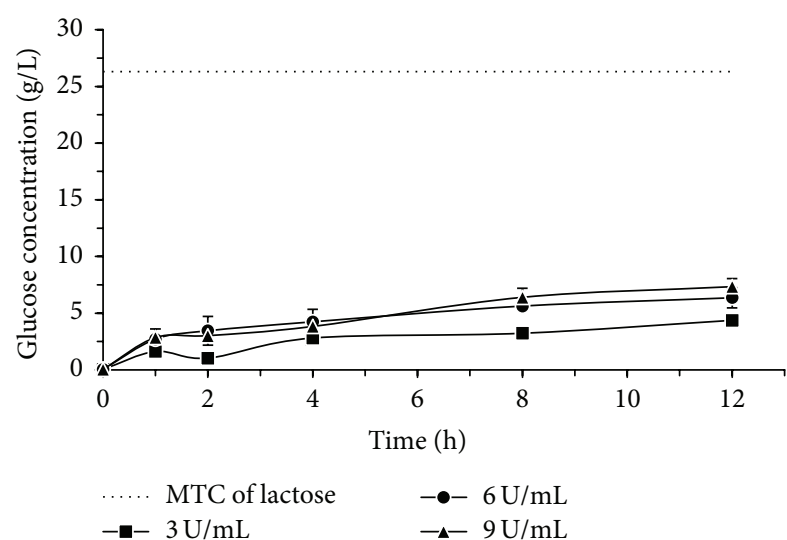

(a)

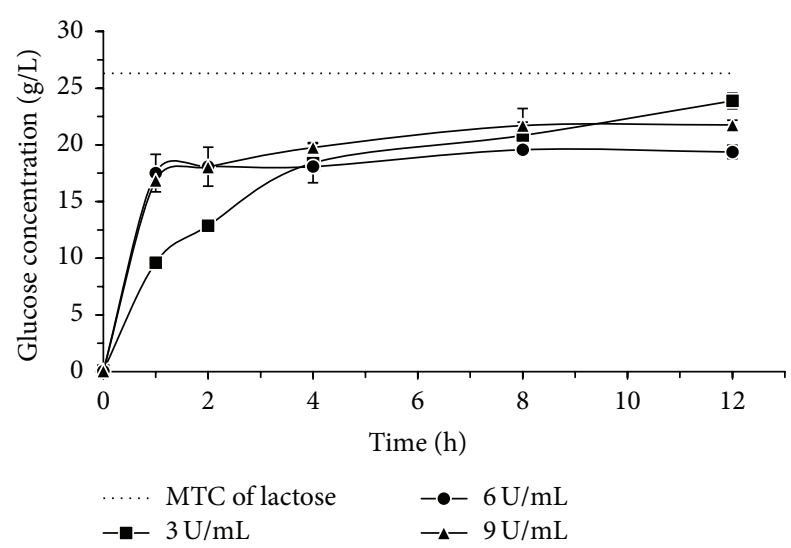

(c)

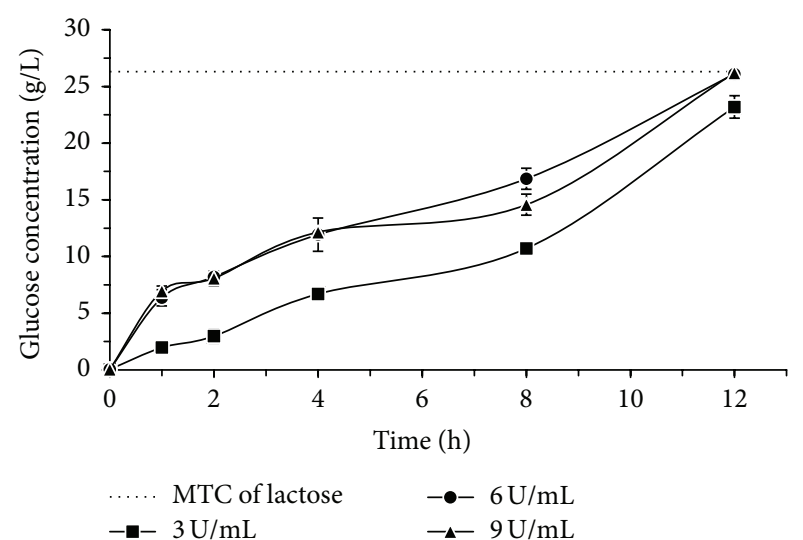

(b)

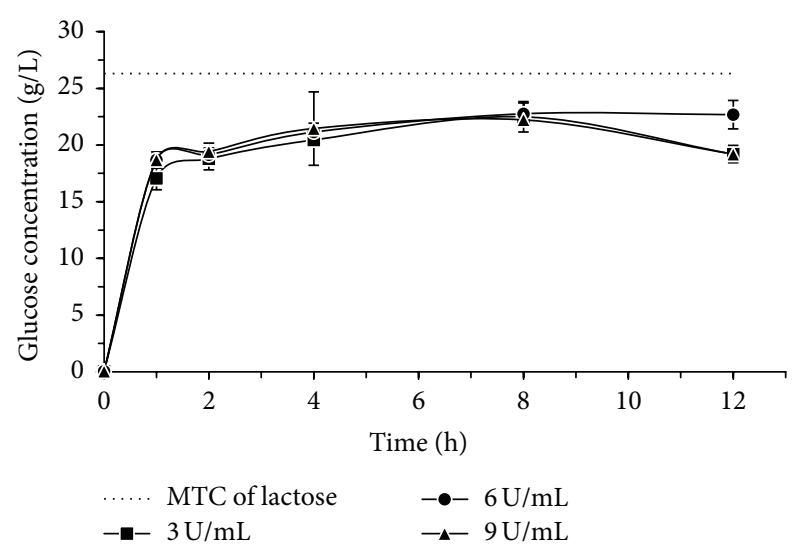

(d)

FIGURE 1: Glucose concentration from the enzymatic lactose hydrolysis of milk using A. oryzae $\beta$-galactosidase, (a) $10^{\circ} \mathrm{C}$, (b) $55^{\circ} \mathrm{C}$, and $\mathrm{K}$. lactis $\beta$-galactosidase, (c) $10^{\circ} \mathrm{C}$, (d) $37^{\circ} \mathrm{C}$. The dotted line in each graph indicates the corresponding glucose concentration to maximum theoretical conversion (MTC) of lactose.

were 3, 6, and $9 \mathrm{U} / \mathrm{mL}$ (one unit of $\beta$-galactosidases activity $(\mathrm{U})$ was defined as the amount of enzyme that liberates 1.0 $\mu$ mole of o-nitrophenol per minute under assay conditions).

The lactose hydrolysis processes of milk, whey, and permeate were performed at low temperature $\left(10^{\circ} \mathrm{C}\right)$ for both enzymes, with the aim of not altering the sensorial and nutritional characteristics of the milk and dairy whey. The enzymatic optimum temperature effect of each commercial $\beta$-galactosidase, $A$. oryzae $\left(55^{\circ} \mathrm{C}\right)$, and $K$. lactis $\left(37^{\circ} \mathrm{C}\right)$ was also evaluated in the hydrolysis process.

According to Campos et al. [17], the $\beta$-galactosidase enzyme has been used at temperatures under optimum value of reaction, in order to avoid bacterial multiplication in the milk, as temperatures around $37^{\circ} \mathrm{C}$ correspond to the optimum condition for the development of various deteriorative and pathogenic microorganisms. The enzymes activity is influenced by multiple environmental factors, among which temperature is one of the most important parameters, and may affect the tridimensional structure or the protein conformation [18].

Comparing the hydrolysis process at $10^{\circ} \mathrm{C}$ and at the optimum temperature of each enzyme, we verified that, under the experimental conditions applied, the temperature variation effect was more expressive for $A$. oryzae $\beta$ galactosidase than for $K$. lactis $\beta$-galactosidase. Figures 1,2 , and 3 show that the lactose hydrolysis of milk, whey, and permeate, respectively, with the fungal enzyme was higher at the optimum temperature in relation to the one at $10^{\circ} \mathrm{C}$; yet for the $K$. lactis enzyme, the glucose concentrations generated from the lactose hydrolysis are similar under both temperatures $\left(10\right.$ and $37^{\circ} \mathrm{C}$ ), regardless of the raw material.

Regarding the enzyme concentration used in the lactose hydrolysis process, we verified that the variation for this parameter had higher influence when the $A$. oryzae $\beta$ galactosidase was used, regardless of the studied raw material. For the K. lactis enzyme, the lactose hydrolysis results only presented the same behavior of the fungal $\beta$-galactosidase when the whey permeate was used as a substrate. The results were similar for the milk and cheese whey hydrolysis, regardless of the tested $K$. lactis enzyme concentration.

Enzyme concentration directly influences lactose hydrolysis, as was already observed in other papers $[19,20]$. Horner et al. [19] evaluated the lactose hydrolysis of raw and pasteurized milk using four commercial Kluyveromyces $\beta$-galactosidases at $2^{\circ} \mathrm{C}$ for $72 \mathrm{~h}$. The authors observed that 
TABLE 1: Efficiency of milk lactose hydrolysis using A. oryzae and $K$. lactis $\beta$-galactosidases in 3, 6, and $9 \mathrm{U} / \mathrm{mL}$ concentrations and $2 \mathrm{~h}$ of reaction.

\begin{tabular}{|c|c|c|c|c|c|c|c|c|}
\hline \multirow{3}{*}{ Enzyme conc. (U/mL) } & \multicolumn{4}{|c|}{ Aspergillus oryzae } & \multicolumn{4}{|c|}{ Kluyveromyces lactis } \\
\hline & \multicolumn{2}{|c|}{$10^{\circ} \mathrm{C}$} & \multicolumn{2}{|c|}{$55^{\circ} \mathrm{C}$} & \multicolumn{2}{|c|}{$10^{\circ} \mathrm{C}$} & \multicolumn{2}{|c|}{$37^{\circ} \mathrm{C}$} \\
\hline & $C_{\text {glu }}(\mathrm{g} / \mathrm{L})$ & $E_{h}(\%)$ & $C_{\text {glu }}(\mathrm{g} / \mathrm{L})$ & $E_{h}(\%)$ & $C_{\text {glu }}(\mathrm{g} / \mathrm{L})$ & $E_{h}(\%)$ & $C_{\text {glu }}(\mathrm{g} / \mathrm{L})$ & $E_{h}(\%)$ \\
\hline 3 & $1.04^{\mathrm{b}}$ & $3.96^{\mathrm{b}}$ & $2.98^{\mathrm{b}}$ & $11.32^{\mathrm{b}}$ & $12.88^{\mathrm{b}}$ & $48.94^{\mathrm{b}}$ & $18.87^{\mathrm{a}}$ & $71.70^{\mathrm{a}}$ \\
\hline 6 & $3.45^{\mathrm{a}}$ & $13.12^{\mathrm{a}}$ & $8.21^{\mathrm{a}}$ & $31.20^{\mathrm{a}}$ & $18.08^{\mathrm{a}}$ & $68.70^{\mathrm{a}}$ & $19.15^{\mathrm{a}}$ & $72.78^{\mathrm{a}}$ \\
\hline 9 & $3.02^{\mathrm{a}}$ & $11.48^{\mathrm{a}}$ & $8.08^{\mathrm{a}}$ & $30.70^{\mathrm{a}}$ & $18.05^{\mathrm{a}}$ & $68.60^{\mathrm{a}}$ & $19.43^{\mathrm{a}}$ & $73.84^{\mathrm{a}}$ \\
\hline
\end{tabular}

${ }^{\mathrm{ab}}$ Means with different superscripts in the same column are significantly different, according to Tukey test $(p<0.05)$.

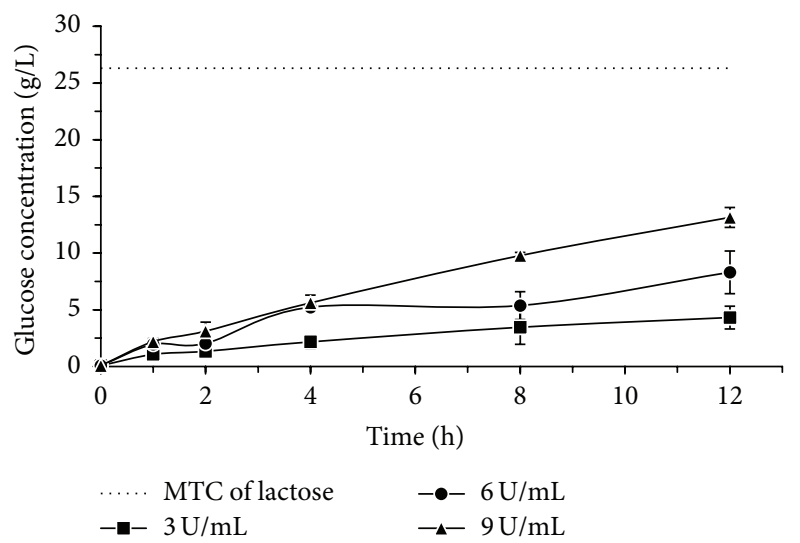

(a)

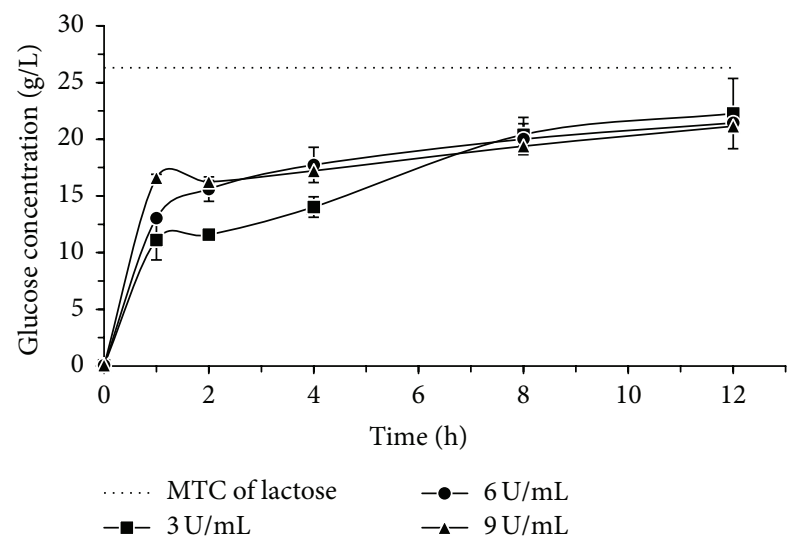

(c)

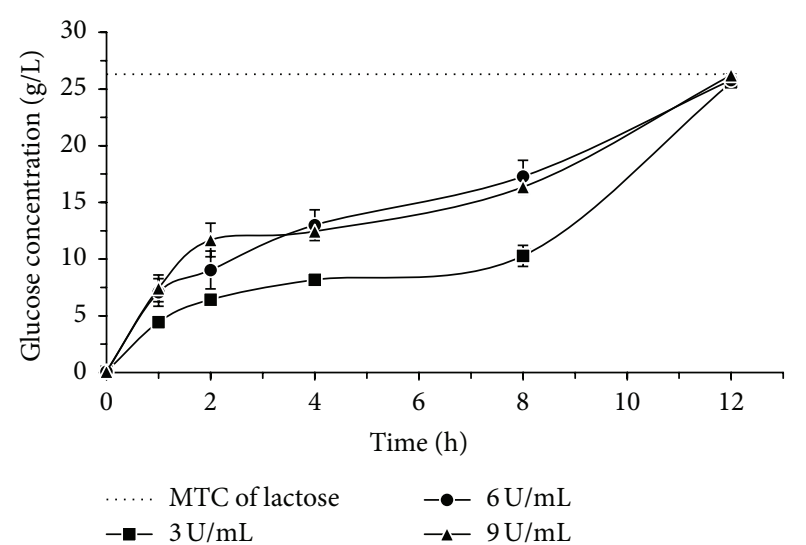

(b)

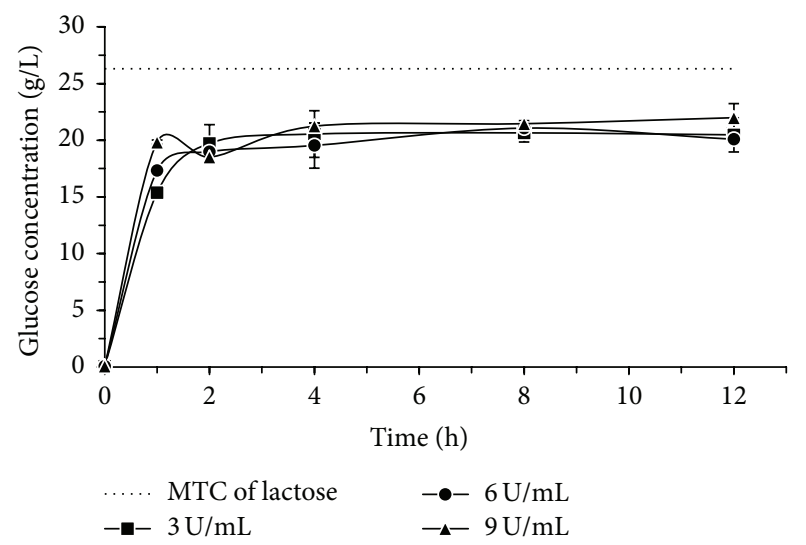

(d)

FIGURE 2: Glucose concentration from the enzymatic lactose hydrolysis of cheese whey using $A$. oryzae $\beta$-galactosidase, (a) $10^{\circ} \mathrm{C}$, (b) $55^{\circ} \mathrm{C}$, and $\mathrm{K}$. lactis $\beta$-galactosidase, (c) $10^{\circ} \mathrm{C}$, (d) $37^{\circ} \mathrm{C}$. The dotted line in each graph indicates the corresponding glucose concentration to maximum theoretical conversion (MTC) of lactose.

the fourfold increase in the enzyme concentration doubled the hydrolyzed lactose concentration in the milk after a $12 \mathrm{~h}$ reaction.

Akgül et al. [20] analyzed the lactose hydrolysis of low fat milk using a commercial $K$. lactis $\beta$-galactosidase in concentrations around $3,6,9$, and $12 \mathrm{U} / \mathrm{mL}$ at $37^{\circ} \mathrm{C}$ for $30 \mathrm{~h}$. The authors verified that the increase of the enzymatic concentration led to a conversion increase in the lactose present in the milk.

In Figures 1, 2, and 3, we observed that for A. oryzae $\beta$-galactosidase the concentrations of glucose gradually increased throughout the whole hydrolysis period, reaching, in $12 \mathrm{~h}$ at optimum temperature, values close to the maximum theoretical conversion of lactose in its respective sugars. As for the $K$. lactis $\beta$-galactosidase, we verified a gradual increase in glucose concentration during the first two hours of reaction, and after that, it remained practically constant throughout the evaluated process, reaching values of about $20 \mathrm{~g} / \mathrm{L}$ of glucose.

Tables 1, 2, and 3 show the efficiency results for the lactose hydrolysis of milk, cheese whey, and permeate, respectively, using the $A$. oryzae (at 10 and $55^{\circ} \mathrm{C}$ ) and $K$. lactis enzymes (at 
TABLE 2: Efficiency of cheese whey lactose hydrolysis using A. oryzae and $K$. lactis $\beta$-galactosidases in 3, 6, and $9 \mathrm{U} / \mathrm{mL}$ concentrations and $2 \mathrm{~h}$ of reaction.

\begin{tabular}{|c|c|c|c|c|c|c|c|c|}
\hline \multirow{3}{*}{ Enzyme conc. (U/mL) } & \multicolumn{4}{|c|}{ Aspergillus oryzae } & \multicolumn{4}{|c|}{ Kluyveromyces lactis } \\
\hline & \multicolumn{2}{|c|}{$10^{\circ} \mathrm{C}$} & \multicolumn{2}{|c|}{$55^{\circ} \mathrm{C}$} & \multicolumn{2}{|c|}{$10^{\circ} \mathrm{C}$} & \multicolumn{2}{|c|}{$37^{\circ} \mathrm{C}$} \\
\hline & $C_{\text {glu }}(\mathrm{g} / \mathrm{L})$ & $E_{h}(\%)$ & $C_{\text {glu }}(\mathrm{g} / \mathrm{L})$ & $E_{h}(\%)$ & $C_{\text {glu }}(\mathrm{g} / \mathrm{L})$ & $E_{h}(\%)$ & $C_{\text {glu }}(\mathrm{g} / \mathrm{L})$ & $E_{h}(\%)$ \\
\hline 3 & $1.34^{\mathrm{b}}$ & $5.10^{\mathrm{b}}$ & $6.43^{\mathrm{b}}$ & $24.44^{\mathrm{b}}$ & $11.58^{\mathrm{b}}$ & $44.00^{\mathrm{b}}$ & $19.73^{\mathrm{a}}$ & $74.98^{\mathrm{a}}$ \\
\hline 6 & $2.04^{\mathrm{ab}}$ & $7.76^{\mathrm{ab}}$ & $9.04^{\mathrm{ab}}$ & $34.36^{\mathrm{ab}}$ & $15.61^{\mathrm{a}}$ & $59.32^{\mathrm{a}}$ & $18.99^{\mathrm{a}}$ & $72.16^{\mathrm{a}}$ \\
\hline 9 & $3.12^{\mathrm{a}}$ & $11.86^{\mathrm{a}}$ & $11.68^{\mathrm{a}}$ & $44.38^{\mathrm{a}}$ & $16.25^{\mathrm{a}}$ & $61.76^{\mathrm{a}}$ & $18.51^{\mathrm{a}}$ & $70.34^{\mathrm{a}}$ \\
\hline
\end{tabular}

${ }^{\mathrm{ab}}$ Means with different superscripts in the same column are significantly different, according to Tukey test $(p<0.05)$.

TABLE 3: Efficiency of whey permeate lactose hydrolysis using A. oryzae and $K$. lactis $\beta$-galactosidases in 3, 6, and $9 \mathrm{U} / \mathrm{mL}$ concentrations and $2 \mathrm{~h}$ of reaction.

\begin{tabular}{|c|c|c|c|c|c|c|c|c|}
\hline \multirow{3}{*}{ Enzyme conc. (U/mL) } & \multicolumn{4}{|c|}{ Aspergillus oryzae } & \multicolumn{4}{|c|}{ Kluyveromyces lactis } \\
\hline & \multicolumn{2}{|c|}{$10^{\circ} \mathrm{C}$} & \multicolumn{2}{|c|}{$55^{\circ} \mathrm{C}$} & \multicolumn{2}{|c|}{$10^{\circ} \mathrm{C}$} & \multicolumn{2}{|c|}{$37^{\circ} \mathrm{C}$} \\
\hline & $C_{\text {glu }}(\mathrm{g} / \mathrm{L})$ & $E_{h}(\%)$ & $C_{\text {glu }}(\mathrm{g} / \mathrm{L})$ & $E_{h}(\%)$ & $C_{\text {glu }}(\mathrm{g} / \mathrm{L})$ & $E_{h}(\%)$ & $C_{\text {glu }}(\mathrm{g} / \mathrm{L})$ & $E_{h}(\%)$ \\
\hline 3 & $2.82^{\mathrm{b}}$ & $10.72^{\mathrm{b}}$ & $8.42^{\mathrm{b}}$ & $32.00^{\mathrm{b}}$ & $7.70^{\mathrm{b}}$ & $29.26^{\mathrm{b}}$ & $13.28^{\mathrm{b}}$ & $50.46^{\mathrm{b}}$ \\
\hline 6 & $4.93^{\mathrm{a}}$ & $18.74^{\mathrm{a}}$ & $11.38^{\mathrm{a}}$ & $43.24^{\mathrm{a}}$ & $12.31^{\mathrm{a}}$ & $46.78^{\mathrm{a}}$ & $16.46^{\mathrm{a}}$ & $62.54^{\mathrm{a}}$ \\
\hline 9 & $4.96^{\mathrm{a}}$ & $18.84^{\mathrm{a}}$ & $13.35^{\mathrm{a}}$ & $50.74^{\mathrm{a}}$ & $14.38^{\mathrm{a}}$ & $54.64^{\mathrm{a}}$ & $18.27^{\mathrm{a}}$ & $69.42^{\mathrm{a}}$ \\
\hline
\end{tabular}

${ }^{\mathrm{ab}}$ Means with different superscripts in the same column are significantly different, according to Tukey test $(p<0.05)$.

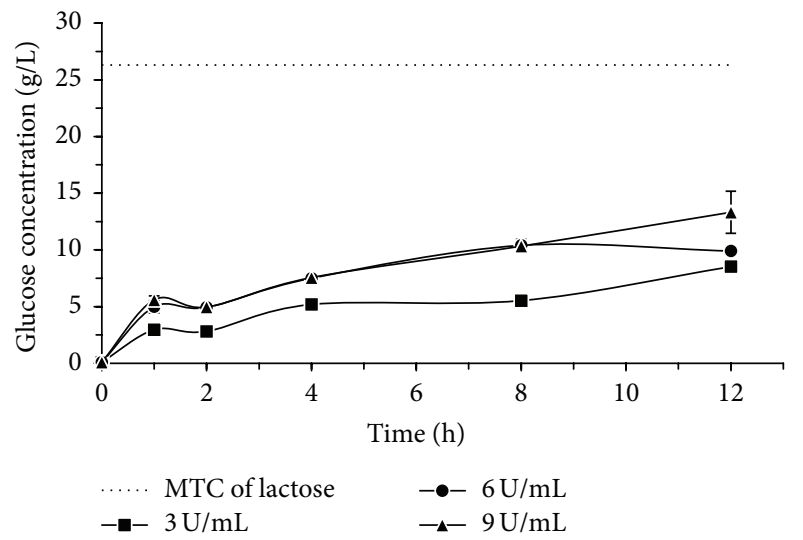

(a)

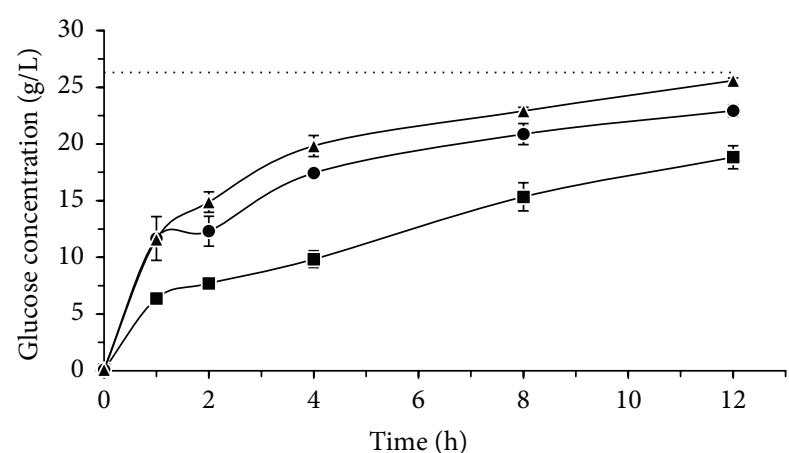

MTC of lactose

$3 \mathrm{U} / \mathrm{mL}$

$-\bullet-6 \mathrm{U} / \mathrm{mL}$

$-\Delta-9 \mathrm{U} / \mathrm{mL}$

(c)

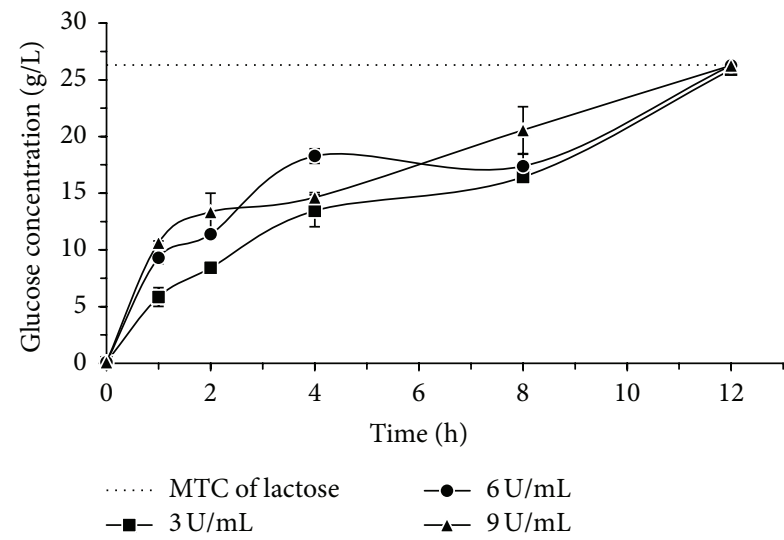

(b)

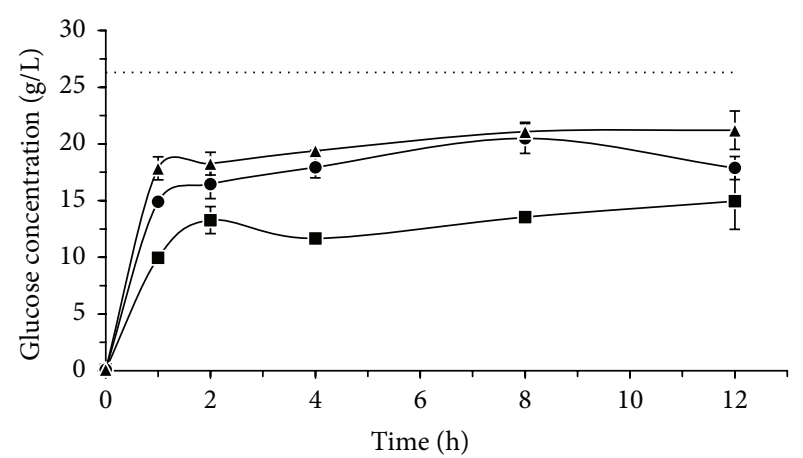

MTC of lactose

$-\bullet-6 \mathrm{U} / \mathrm{mL}$

$-\mathbf{-}-9 \mathrm{U} / \mathrm{mL}$

(d)

Figure 3: Glucose concentration from the enzymatic lactose hydrolysis of whey permeate using $A$. oryzae $\beta$-galactosidase, (a) $10^{\circ} \mathrm{C}$, (b) $55^{\circ} \mathrm{C}$, and $\mathrm{K}$. lactis $\beta$-galactosidase, (c) $10^{\circ} \mathrm{C}$, (d) $37^{\circ} \mathrm{C}$. The dotted line in each graph indicates the corresponding glucose concentration to maximum theoretical conversion (MTC) of lactose. 
10 and $37^{\circ} \mathrm{C}$ ) after $2 \mathrm{~h}$ of reaction. The enzymatic concentrations used were 3,6 , and $9 \mathrm{U} / \mathrm{mL}$.

The hydrolysis efficiency was evaluated in $2 \mathrm{~h}$ reaction taking into account the possible industrial application of the enzymes in the referred process.

No significant difference $(p<0.05)$ was observed between the efficiencies of the lactose hydrolysis in milk, whey, and permeate when using 6 and $9 \mathrm{U} / \mathrm{mL}$ concentrations, for both enzymes at optimum temperatures and at $10^{\circ} \mathrm{C}$. However, for the $3 \mathrm{U} / \mathrm{mL}$ concentration, efficiency was significantly lower $(p<0.05)$ for most of the conditions evaluated.

During $2 \mathrm{~h}$ of reaction, for the same enzyme concentration, the $K$. lactis $\beta$-galactosidase presented higher hydrolysis efficiency than the $A$. oryzae $\beta$-galactosidase. This higher lactose conversion rate was verified even when the $K$. lactis enzyme was used at $10^{\circ} \mathrm{C}$ and the $A$. oryzae one at the optimum reaction temperature.

We observed a higher milk and whey lactose hydrolysis efficiency when using the $K$. lactis $\beta$-galactosidase and in the permeate when using the $A$. oryzae $\beta$-galactosidase. These results probably occurred due to the different $\mathrm{pH}$ values of the raw materials. The $\mathrm{pH}$ values of reconstructed milk and whey used in this study presented values of about 6.8 and 6.4 , respectively. The whey permeate presented a $\mathrm{pH}$ value of around 5.9. The $A$. oryzae $\beta$-galactosidase used presents an optimum $\mathrm{pH}$ in a 4.5-5.0 range, and the one from $K$. lactis presents $\mathrm{pH}$ between 7.3 and 7.7 .

When using the $A$. oryzae $\beta$-galactosidase in 6 and $9 \mathrm{U} / \mathrm{mL}$ concentrations, we verified a total lactose hydrolysis in milk, whey, and permeate at $55^{\circ} \mathrm{C}$ at the end of $12 \mathrm{~h}$ of enzymatic reaction (Figures 1(b), 2(b), and 3(b)). The hydrolysis rate obtained in the present study was higher than the one described by Haider and Husain [21], who evaluated the lactose hydrolysis process in milk and whey using the $A$. oryzae $\beta$-galactosidase, at $37^{\circ} \mathrm{C}$, in 0.88 and $0.44 \mathrm{U} / \mathrm{mL}$ concentrations, respectively. The authors observed a maximum hydrolysis of $61 \%$ for milk after $4 \mathrm{~h}$ of reaction and of $70 \%$ for whey after $3 \mathrm{~h}$ of reaction.

The maximum lactose hydrolysis efficiencies, in $2 \mathrm{~h}$ of reaction, were obtained using a $K$. lactis $\beta$-galactosidase at $37^{\circ} \mathrm{C}$ (Tables 1,2 , and 3). In the milk, the highest conversion rate observed was $73.84 \%$ with $9 \mathrm{U} / \mathrm{mL}$ of enzymes. For the whey, the maximum hydrolysis efficiency was $74.98 \%$ with $3 \mathrm{U} / \mathrm{mL}$ of enzymes. As for the permeate, it was $69.42 \%$ with $9 \mathrm{U} / \mathrm{mL}$ of enzymes. For the $K$. lactis $\beta$-galactosidase, in none of the conditions evaluated, a $100 \%$ hydrolysis efficiency was reached (Figures 1(c), 1(d), 2(c), 2(d), 3(c), and $3(d))$. However, the obtained results may be considered as satisfactory, since, according to Hourigan [22], the lactose concentrations reduction from 70 to $80 \%$ in dairy products is enough for most people who are lactose intolerant.

Higher milk lactose hydrolysis values using the Kluyveromyces enzyme are described in the literature. Horner et al. [19], using commercial Kluyveromyces $\beta$ galactosidases in $3,6,9$, and $12 \mathrm{U} / \mathrm{mL}$ concentrations, at $2^{\circ} \mathrm{C}$ after $48 \mathrm{~h}$ of reaction, verified values of approximately $100 \%$ lactose hydrolysis efficiency for pasteurized milk. Antunes et al. [23] evaluated the physicochemical, microbiological, and sensorial characteristics of delactosed milk using $20 \mathrm{U} / \mathrm{mL}$ of the $K$. lactis $\beta$-galactosidase enzyme at $10^{\circ} \mathrm{C}$. Under these conditions, the authors verified a hydrolysis rate of $90 \%$ in $21 \mathrm{~h}$ of reaction.

\section{Conclusion}

The results obtained indicate that at temperature of $10^{\circ} \mathrm{C}$ the $K$. lactis $\beta$-galactosidase enzyme is more efficient in the milk, cheese whey, and whey permeate lactose hydrolysis when compared to $A$. oryzae. However, in the enzyme reaction time and concentration conditions evaluated, 100\% lactose hydrolysis was not reached using the $K$. lactis $\beta$-galactosidase. The total lactose hydrolysis in whey and permeate was obtained with the $A$. oryzae enzyme, when using its optimum temperature $\left(55^{\circ} \mathrm{C}\right)$, at the end of $12 \mathrm{~h}$ of reaction, regardless of the enzyme concentration used. For milk lactose, this result occurred in the concentrations of 6 and $9 \mathrm{U} / \mathrm{mL}$, with the same time and temperature conditions.

\section{Conflict of Interests}

The authors declare that there is no conflict of interests regarding the publication of this paper.

\section{Acknowledgments}

Thanks are due to CNPq and CAPES for the scholarships, to UNIVATES for the financial support granted for this research paper, and to Prozyn Company for donating the enzymes.

\section{References}

[1] P. C. Pereira, "Milk nutritional composition and its role in human health," Nutrition, vol. 30, no. 6, pp. 619-627, 2014.

[2] R. P. Heaney, "Dairy intake, dietary adequacy, and lactose intolerance," Advances in Nutrition, vol. 4, no. 2, pp. 151-156, 2013.

[3] V. C. Sgarbieri, "Physiological-functional properties of milk whey proteins," Revista de Nutricao, vol. 17, no. 4, pp. 397-409, 2004.

[4] G. Moulin and P. Galzy, "Whey, a potential substrate for biotechnology," Biotechnology and Genetic Engineering Reviews, vol. 1, no. 1, pp. 347-374, 1984.

[5] R. L. P. de Andrade and J. F. P. Martins, "Influence of sweet potato starch at permeate whey viscosity," Food Science and Technology, vol. 22, no. 3, pp. 249-253, 2002.

[6] M. Wyatt, Whey Proteins: Functional Properties, Production and Health Benefits, Nova Science, 2014.

[7] R. Mattar and D. F. de Campos Mazo, "Intolerância à lactose: mudança de paradigmas com a biologia molecular," Revista da Associação Médica Brasileira, vol. 56, no. 2, pp. 230-236, 2010.

[8] A. Shaukat, M. D. Levitt, B. C. Taylor et al., "Systematic review: effective management strategies for lactose intolerance," Annals of Internal Medicine, vol. 152, no. 12, pp. 797-803, 2010.

[9] J. Babu, S. Kumar, P. Babu, J. H. Prasad, and U. C. Ghoshal, "Frequency of lactose malabsorption among healthy southern and northern Indian populations by genetic analysis and lactose hydrogen breath and tolerance tests," American Journal of Clinical Nutrition, vol. 91, no. 1, pp. 140-146, 2010. 
[10] Y. Khabarova, S. Tornianen, S. Tuomisto et al., "Lactase nonpersistent genotype influences milk consumption and gastrointestinal symptoms in Northern Russians," BMC Gastroenterology, vol. 11, article 124, 6 pages, 2011.

[11] Q. Husain, “ $\beta$ galactosidases and their potential applications: a review," Critical Reviews in Biotechnology, vol. 30, no. 1, pp. 4162, 2010.

[12] P. S. Panesar, S. Kumari, and R. Panesar, "Potential applications of immobilized $\beta$-galactosidase in food processing industries," Enzyme Research, vol. 2010, Article ID 473137, 16 pages, 2010.

[13] M. I. G. Siso, "The biotechnological utilization of cheese whey: a review," Bioresource Technology, vol. 57, no. 1, pp. 1-11, 1996.

[14] A. Coté, W. A. Brown, D. Cameron, and G. P. Van Walsum, "Hydrolysis of lactose in whey permeate for subsequent fermentation to ethanol," Journal of Dairy Science, vol. 87, no. 6, pp. 1608-1620, 2004.

[15] A. A. Koutinas, H. Papapostolou, D. Dimitrellou et al., "Whey valorisation: a complete and novel technology development for dairy industry starter culture production," Bioresource Technology, vol. 100, no. 15, pp. 3734-3739, 2009.

[16] Z. Mlichová and M. Rosenberg, "Current trends of $\beta$ galactosidase application in food technology," Journal of Food and Nutrition Research, vol. 45, no. 2, pp. 47-54, 2006.

[17] T. C. A. S. Campos, W. K. D’Almeida, L. C. A. Alegro, S. M. Roig, and H. H. Suguimoto, "Use of $\beta$-galactosidase on hydrolysis of milk lactose in low temperature," Unopar Científica Ciências Biológicas e da Saúde, vol. 11, pp. 51-54, 2009.

[18] E. Jurado, F. Camacho, G. Luzón, and J. M. Vicaria, "Kinetic models of activity for $\beta$-galactosidases: influence of $\mathrm{pH}$, ionic concentration and temperature," Enzyme and Microbial Technology, vol. 34, no. 1, pp. 33-40, 2004.

[19] T. W. Horner, M. L. Dunn, D. L. Eggett, and L. V. Ogden, “ $\beta$ galactosidase activity of commercial lactase samples in raw and pasteurized milk at refrigerated temperatures," Journal of Dairy Science, vol. 94, no. 7, pp. 3242-3249, 2011.

[20] F. B. Akgül, E. Demirhan, and B. Özbek, "A Modelling study on skimmed milk lactose hydrolysis and $\beta$-galactosidase stability using three reactor types," International Journal of Dairy Technology, vol. 65, no. 2, pp. 217-231, 2012.

[21] T. Haider and Q. Husain, "Immobilization of $\beta$-galactosidase by bioaffinity adsorption on concanavalin A layered calcium alginate-starch hybrid beads for the hydrolysis of lactose from whey/milk," International Dairy Journal, vol. 19, no. 3, pp. 172177, 2009.

[22] J. A. Hourigan, "Nutritional implication of lactose," Australian Journal of Dairy Technology, vol. 39, pp. 114-120, 1984.

[23] A. E. C. Antunes, A. T. S. e Alves, D. A. Gallina et al., "Development and shelf-life determination of pasteurized, microfiltered, lactose hydrolyzed skim milk," Journal of Dairy Science, vol. 97, no. 9, pp. 5337-5344, 2014. 

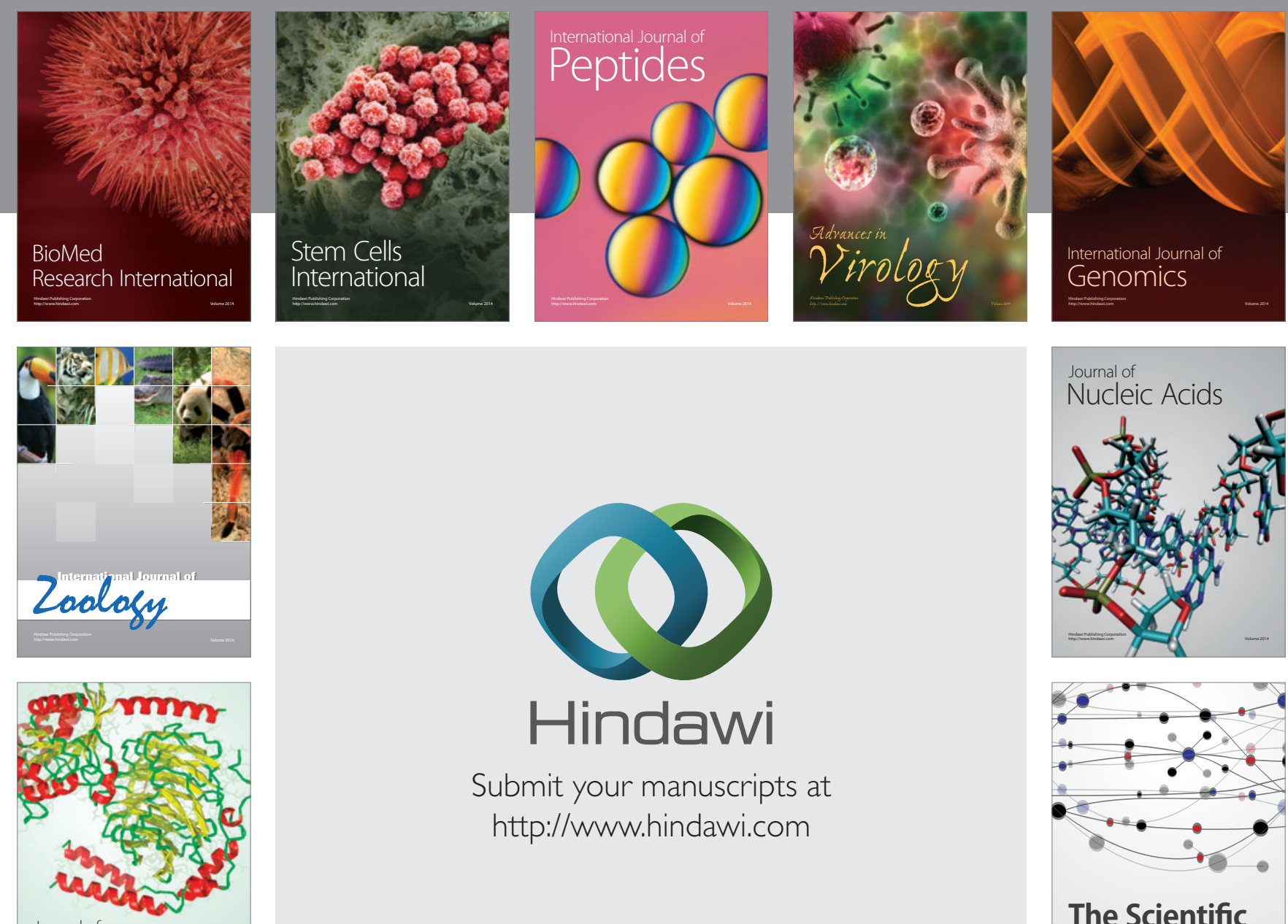

Submit your manuscripts at

http://www.hindawi.com

Journal of
Signal Transduction
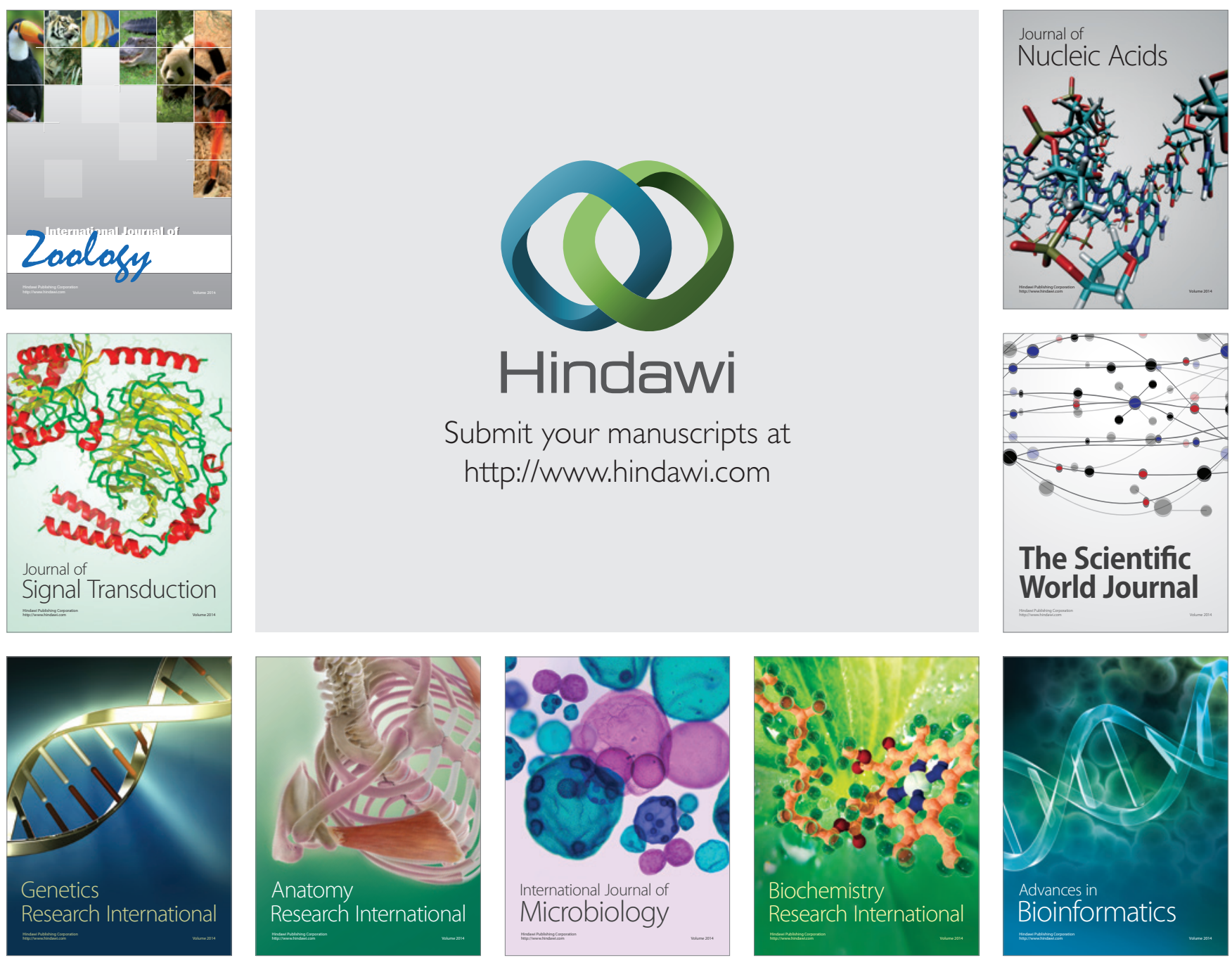

The Scientific World Journal
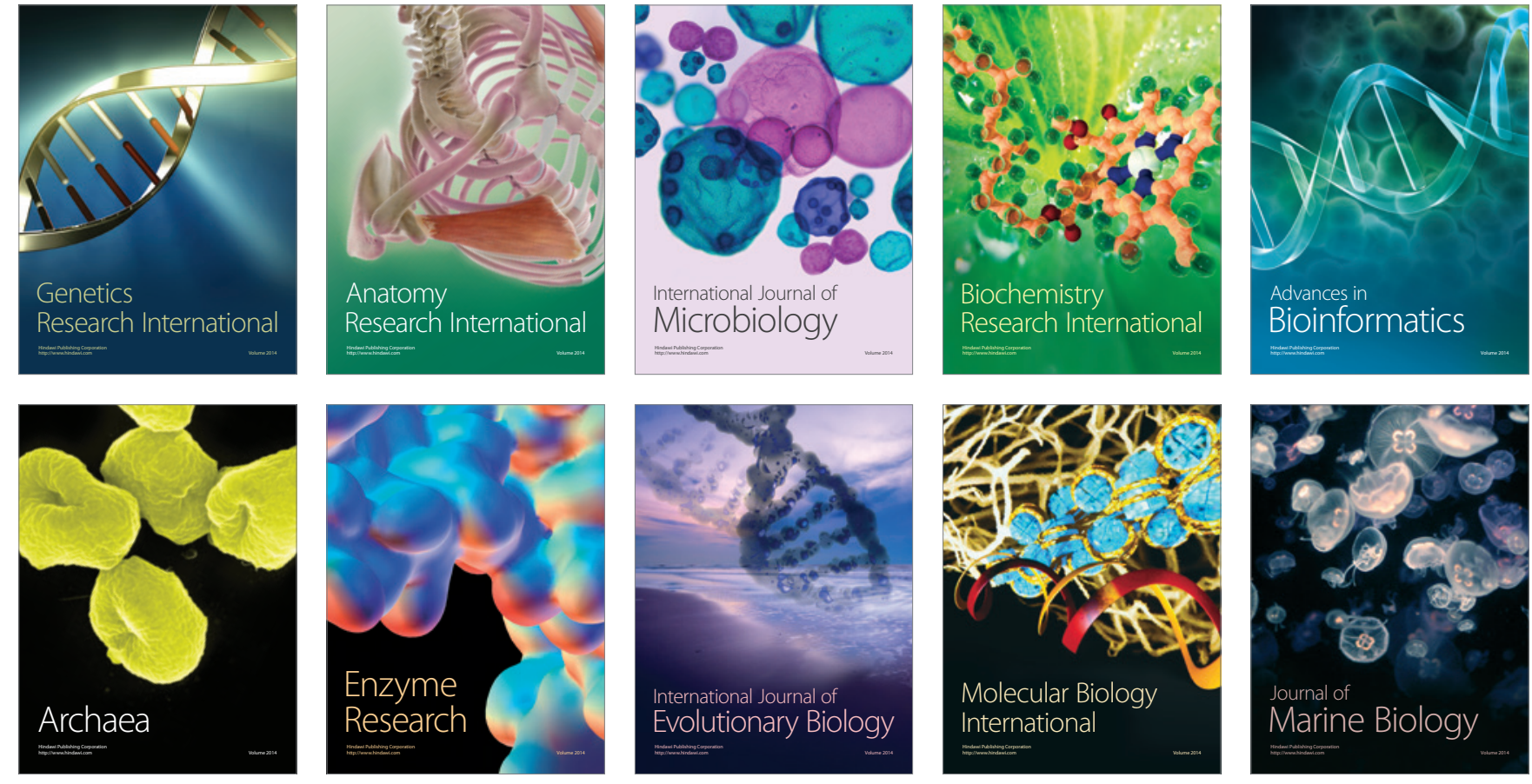